\title{
EXPLORING 3D MOLECULAR STUDIES OF DIKETOPIPERAZINE ANALOGUES ON Staphylococcus aureus DEHYDROSQUALENE SYNTHASE USING GLIDE-XP ${ }^{1}$
}

\author{
Broto Santoso \\ Faculty of Pharmacy, Muhammadiyah University of Surakarta \\ broto.santoso@gmail.com
}

\begin{abstract}
There is a strong correlation between $3 D$ molecular docking result with dehydrosqualene synthase protein and antibacterial activity against Staphylococcus aureus (S. aureus) of the pyrazoline analogues. The enzyme has been known as important protein for the synthesis of staphyloxanthin in S. aureus. Diketopiperazine analogues have similar structure to pyrazoline. Glide-XP, Schrodinger application that seeks for molecular docking screening between ligand and protein target is designed for speed, efficiency, and accuracy to conduct discovery efforts. The research report the three-dimension molecular studies diketopiperazine analogues for their antibacterial activity on dehydrosqualene synthase of S. aureus using Glide-XP. Analogues compound of diketopiperazine and curcumin has been calculated their geometry optimization using Gaussian-Density Functional Theory method. These 3D-optimized ligands along with reference ligands obtained from bindingDB database, MIMICs fingerprint shape screening and the compound from previous research were performed on dehydrosqualene synthase (2ZCO) for their docking score. The lowest values docking score were analyzed with multiple linear regressions. The results suggest that the diketopiperazine framework is a prospective template for modification and optimization to accomplish better potency of antibacterial activity in laboratory testing.
\end{abstract}

Keywords: diketopiperazine, Glide-XP, docking score, Staphylococcus aureus, multiple linear regression.

\begin{abstract}
ABSTRAK
Terdapat korelasi positif antara hasil molecular docking ligan-protein dehidroskualen sintase dan aktivitas antibakteri terhadap Staphylococcus aureus (S. aureus) analog pirazolon. Protein enzim ini merupakan komponen utama dalam biosintesis stafiloksantin pada $S$. aureus. Analog diketopiperazin memiliki kemiripan struktur dengan pirazolon. Glide-XP merupakan aplikasi dalam Schrodinger yang digunakan untuk skrining molecular docking antara ligan dan protein dan didesain lebih cepat, efisien dan akurat untuk memenuhi kebutuhan dalam penemuan senyawa baru. Penelitian ini melaporkan hasil studi molekular-3D analog diketopiperazin untuk aktivitas antibakteri terhadap enzim dehidroskualen sintase S. aureus menggunakan Glide-XP. Molekul analog diketopiperazin dan kurkumin telah dilakukan optimasi geometri menggunakan metode Gaussian-Density Functional Theory (DFT). Semua molekul yang telah dioptimasi bersama dengan ligan pembanding yang diperoleh dari database BindingDB, database MIMICs dengan pendekatan fingerprint shape dan molekul-molekul dari penelitian terdahulu dilakukan molecular docking pada protein dehidroskualen sintase untuk memperoleh docking score. Nilai docking score terendah dianalisis dengan multiple linear regression dan hasilnya menyatakan bahwa inti diketopiperazin merupakan template yang prospektif untuk modifikasi dan optimasi dalam memperoleh potensi antibakteri yang lebih baik di pengujian laboratorium.
\end{abstract}

Kata Kunci: diketopiperazine, Glide-XP, docking score, Staphylococcus aureus, multiple linear regression.

\footnotetext{
This article has been presented at The $24^{\text {th }}$ Federation of Asian Pharmaceutical Associations Congress (FAPA) in Bali, Indonesia on September 13-16, 2012.

\section{INTRODUCTION}

Health problem in Indonesia increase rapidly, especially the use of antibiotics that cause higher resistance accident related to higher morbidity, mortality, and medical cost. Irrational use of antibiotic is the primary source of antibiotic resistance. The habit can develop and create bacterial strains resistant

to antibacterial agents faster. Staphylococcus aureus is one of the most important pathogens that predominantly produce post operative and community-acquired infections, with methicillin- resistant $S$. aureus causing a serious health threat (Bhatia et al, 2010; Triyana, 2009). The microbial have been resistant to penicillin, oxacillin, and other beta-
} 
lactam antibiotics. In Asia, ciprofloxacin resistant S. aureus reached 37\%, methicillin (MRSA) in Taiwan 60\%, China 20\%, Hong Kong 70\%, Philipines 5\%, Singapore 60\%, and Korea over $70 \%$. Sensitivity pattern of MRSA in Indonesia against meropenem slightly decreased, as well as to other antibiotics ranged from 1-60\% (Mardiastuti et al, 2007; Cha et al, 2005).

Other research state that patients of three referral Hospital East Java and Bali (Indonesia) have been known to $3 \%$ among 2500 patients carried MRSA isolates (Santosaningsih et al, 2008 in Radiono, 2011). And the bacteria of $S$. aureus has rate of resistance to trimethoprim/sulfamethoxazole and tetracycline in Surabaya was higher than in Semarang (Lestari et al, 2008). Staphyloxanthin, the golden carotenoid pigment of $S$. aureus as a virulence factor, can react with, and thus deactivate the reactive oxygen species (ROS) and host neutrophilbased killing produced during the inflammatory response. The process makes $S$. aureus resistant to innate immune clearance (Bhatia et al, 2010; Song et al, 2009; Liu et al, 2008; Liu et al, 2005). Structure of dehydrosqualene synthase that responsible for bacterial survival during infections has been identified and studied as protein model to developing potent and selective inhibitors of an important virulence factor in $S$. aureus by doing 3D molecular docking of ligand-receptor (Bhatia et al, 2010; Parameshwar et al, 2009; Song et al, 2009).

There is a strong correlation between 3D molecular docking result with dehydrosqualene synthase protein and antibacterial activity against $S$. aureus of the pyrazoline analogues. The results indicate that addition of groups which increase hydrophobic and steric interactions of pyrazoline will promote the activity of the new pyrazoline analogues against MRSA bacteria. Diketopiperazine analogues have similar structure to pyrazoline. One of them has been tested its antibacterial activity against $S$. aureus (will published as Santoso et al, 2012; Bhatia et al, 2010). Diketopiperazine are analogues compounds of curcumin as first lead compound. Curcumin derivates and analogues have been developed and studied for its biological activity. Its antibacterial activity is very weak and functional group of phenolic has the responsibility for it (Naz et al, 2010; Sunilson et al, 2009; Rai et al, 2008; Cikrikci et al, 2008). Past research has proven that diketopiperazine analogues has antimicrobial activity (Shani et al, 2011; Villemin and Alloum, 1990).

Molecular modeling techniques have shown its success in helping to accelerate the process of screening and discovery of potential compounds ready to market. Initially, AutoDock has started the method followed various other software either free or licensed. Glide-XP is an improved-module in the Schrodinger Maestro which has been proven helpful Astra Zeneca and Wyeth Pharmaceuticals to develop their new product (Waszkowycz et al, 2011; Cross et al, 2009; Trylska et al, 2007; Friesner et al, 2006; Xiaoqi and Zhehao, 2006; Krovat et al, 2005; Kubinyi, 1998). Santoso (2010) has investigated molecular docking result of diketopiperazine analogues on tubulin, the limiting factor in the cycle process of breast cancer in cell line T47D using AutoDock and Glide-XP (Santoso, 2011a; Da'i et al, 2007). The results confirm that the molecular docking capabilities and performance of GlideXP slightly different and better than AutoDock. Other previous studies of 3D-molecular screening of diketopiperazine have been carried out using AutoDock-Vina compared to fingerprint shape of MIMICs database (Santoso, $2011^{b}$ ). The aim of the study is to explore 3Dmolecular binding modes of diketopiperazine analogues on dehydrosqualene synthase of $S$. aureus using Glide-XP.

\section{MATERIAL AND METHODS}

Appliances: personal computer with specifications: 1) the Gaussian-DFT calculations using Intel Core2Quad processor $2.4 \mathrm{GHz}$, NVidia 7300GT 256MB with 4GB RAM and 2) on molecular screening using intel i5 QuadCore processor $2.4 \mathrm{GHz}$, ATI Mobility Radeon HD 545v 512MB with 4GB RAM and intel i7 QuadCore processor $3.4 \mathrm{GHz}$, ATI Radeon HD 6670 1GB with 8GB RAM.

Tested ligands: 3D geometry optimized molecules of diketopiperazine analogues, curcumin analogues, curcumin, were obtained with Gaussian-Density Functional Theory (B3LYP) calculation.

Protein structure and preparation: 3D Xray crystallized structure of the $C$ (30) carotenoid dehydrosqualene synthase from Staphylococcus aureus (PDB: 2ZCO, resolution $=1.58 \AA$ ) was downloaded from the Protein Data Bank (Dutta et al, 2009). The downloaded protein has single chain

A with 284 residues and contains 627 water molecules of crystallization. The protein structure was

prepared using the protein preparation module of Schrödinger software. The final modeled protein was taken as receptor protein and found the most suitable-binding site using sitemap script of Schrödinger.

Reference ligands: $a$ set of MIMICs reference compounds obtained by online 
screening of the 3D-MIMICs database in the following procedure: target protein (crystal structure of dehydrosqualene synthase obtained from www.pdb.org) is uploaded into a database, amino acids (residue) of the binding site pocket were selected by referring to research of Bhatia et al (2010), then fingerprint- based filtering of shaped similarity scoring method was selected and submitted to obtain a maximum of 200 reference compounds (generated by using Rotate v1.0). All downloadable reference compounds serve as inputs in next step of molecular screening using Glide-XP. Other reference compounds are acquired from bindingDB database with source of dehydrosqualene synthase (optimized with Vconf v2.0) and tested compounds of Bhatia et al (2010) research which have optimized by LigPrep.

Molecular screening procedure: all the selected compounds that have been 3Doptimized geometry along with the reference ligands were docked for finding their docking score on dehydrosqualene synthase (2ZCO) using Glide-XP. These was done by doing protein preparation wizard for 2ZCO, making grid box area for molecular interaction, importing all the compounds in Maestro workspace table, and docking them on grid box with Glide-XP to get docking score value. The results were analyzed with Glide-XP and Canvas.

\section{RESULTS AND DISCUSSION Geometry Optimization}

All ligands structures have performed geometry optimization to obtain 3D molecular using one of these methods: DFT calculation with B3LYP/6-31(g) algorithm, Rotate ver. 1.0, Vconf v2.0, and LigPrep. The results of geometry optimization of diketopiperazine analogues, reference ligand obtained from MIMICs and bindingdb database, and Bhatia's molecules showed in the top two of each groups (Figure 1). The numbers of ligands involved are 388 molecules, with details as follows: 61 molecules are analogues of diketopiperazine, 200 molecules of MIMICs database, 57 molecules from bindingdb database, and 70 molecules generated from Bhatia research data. Selected molecules in Figure 1 were the best two of each group for docking score result using Glide-XP and 3Dposition both when combined together. Figure 1 described their docked conformation virtually coincides.

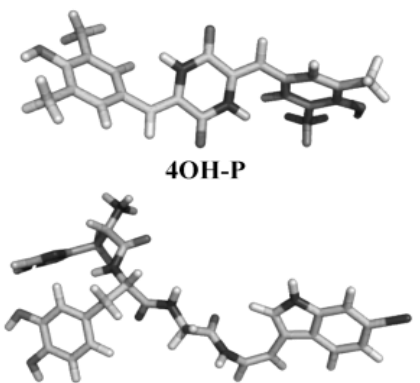

MMs02489377

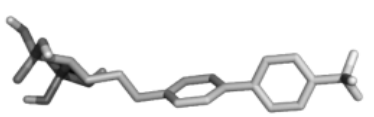

BindingDB_50292847

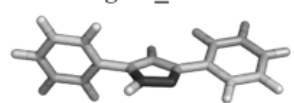

Bhatia 51
Figure 1- Structure of 3D-optimized geometry of top two of each groups

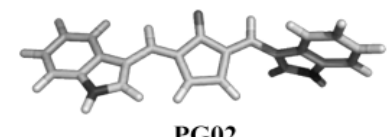

PG02

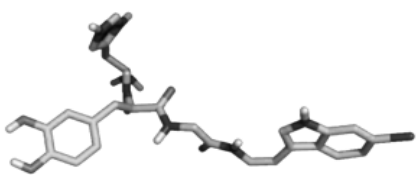

MMs02489379
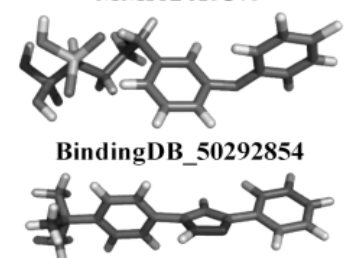

Bhatia 52

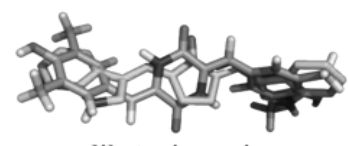

diketopiperazine

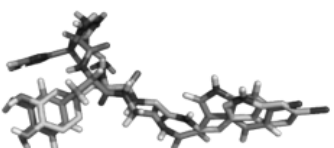

MMsMIMICs

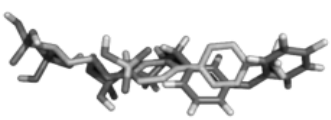

BindingDB

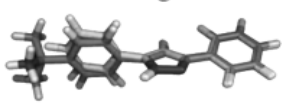

Bhatia molecules

: diketopiperazine analogues, reference ligand obtained from MIMICs and bindingdb database, and Bhatia's molecules (reproduced by PyMol).

\section{Protein Target Site Map}

Protein target dehydosqualene

synthase (2ZCO obtained from www.pdb.org)

were prepared using Maestro: Protein Preparation Wizard with default parameter. As can be seen in Figure 2, the crystal of dehydrosqualene synthase consists of a single chain and conformation stability of the position of amino acid residue which result of protein preparation presented in the Ramachandran plot. Almost all amino acid residues are in yellow and red areas on the

\section{Ramachandran Plot.}

Bhatia et al (2010) states that there are multiple binding sites pocket on the target protein of dehydosqualene synthase (2ZCO). The results of site mapping using Maestro, 2ZCO has 4 positions binding site pocket as shown in Figure 2 with the biggest volume site location in sitemap_site_1. Previous research for searching 2ZCO site map have been done using Q-Sitefinder online and gained the biggest binding site pocket volume in the same location (Santoso, 2011b). 


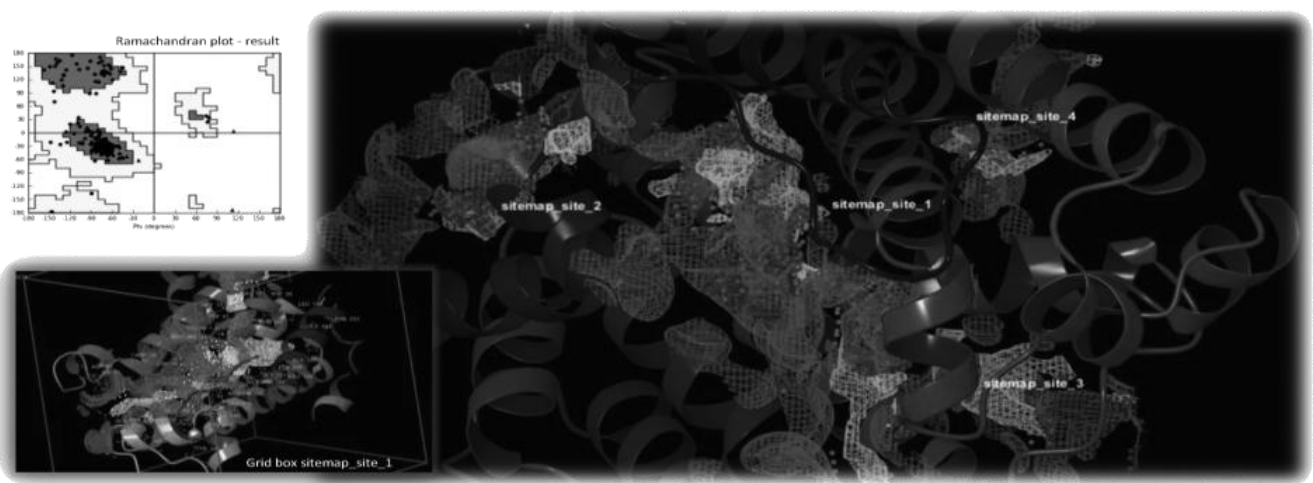

Molecular screening

Figure 2- Result of binding site mapping of dehydosqualene synthase (2ZCO) using Maestro.

Molecular docking was performed by using a maximized grid box with center of point of sitemap_site_1 (Figure 2) because crystal structure of dehydrosqualene synthase is not obtained in conjunction with specific ligands that can serve as a molecular template (Figure 2). Results of binding energy selected ligands represented by GScore (GlideScore or Docking Score in GlideXP) are shown in Figure 3. The highest GScore is given by molecules of the bindingdb and MIMICs, then Bhatia et al (2010) molecules, and the lowest GScore belong to diketopiperazine analogues. The result showed.

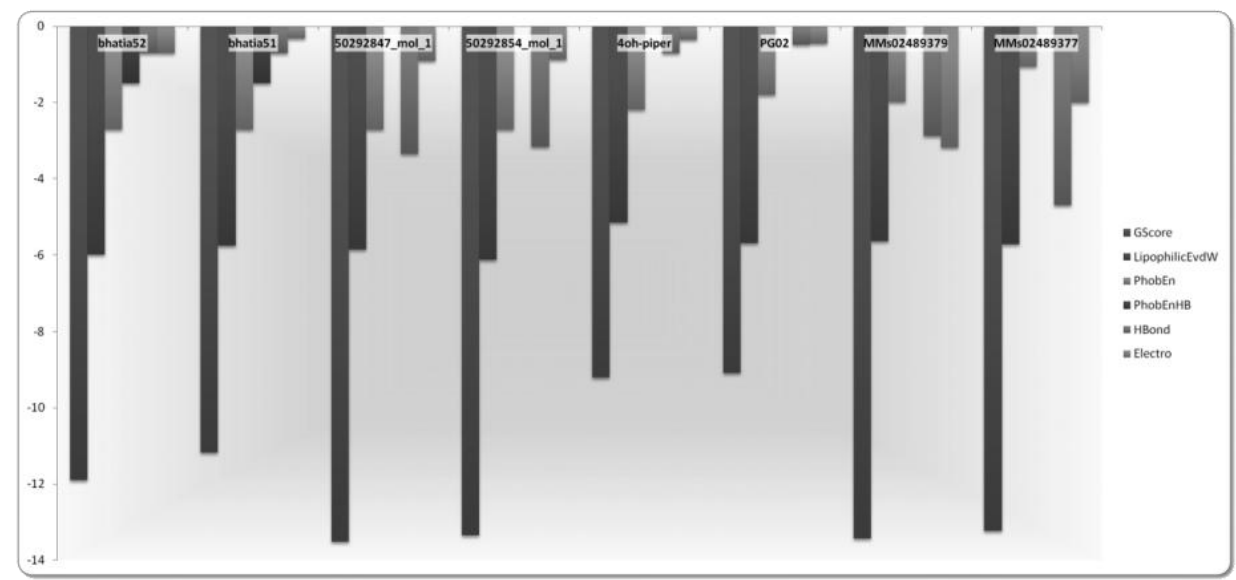

Figure 3- GScore (kcal/mol) of selected ligands of 3D-molecular screening using GlideXP on Staphylococcus aureus dehydrosqualene synthase protein (2ZCO), diketopiperazine analogues $=4 \mathrm{OH}$-piper and PG02; with reference ligands from Bhatia et al research molecules, bindingdb and MIMICs database.

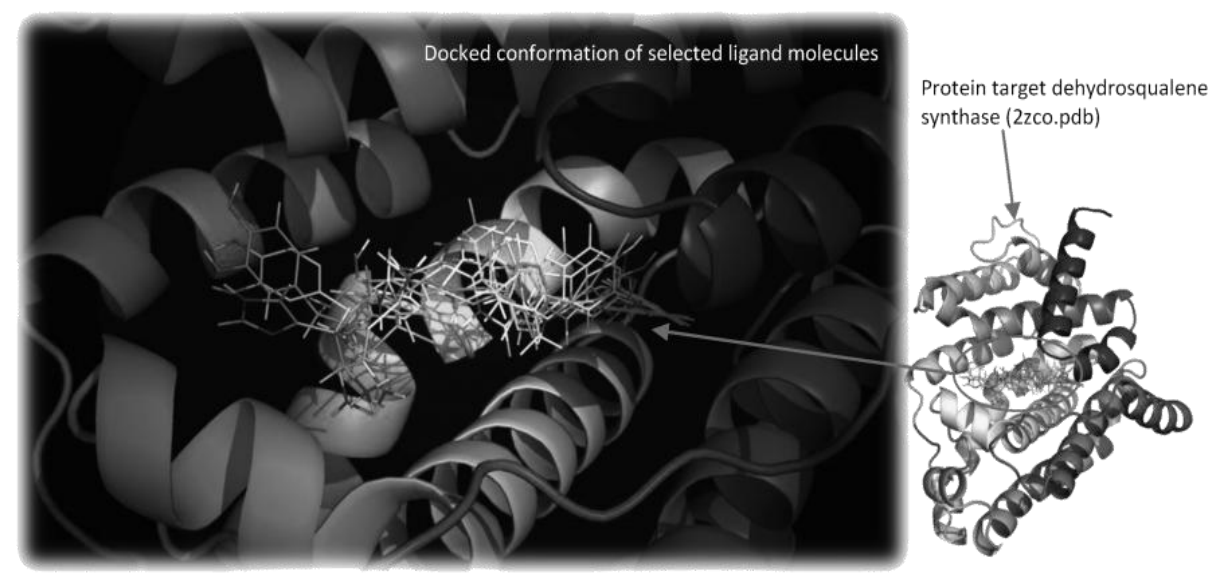

Figure 4- Secondary structure (cartoon) representation of the active site of dehydrosqualene synthase protein with docked conformation of selected ligand molecules using GlideXP (images is reproduced by PyMol).

that the GScore value is influenced by LipophilicEvdW (hydrophobic grid potential and fraction of the total protein-ligand Van der Waals energy), PhobEn (hydrophobic enclosure reward), PhobEnHB (reward for hydrophobically packed $\mathrm{H}$-Bond), and HBond (hydrogen-bonding). The Electro (electrostatic rewards) value is not proportional to GScore thus its contribution is excluded. Figure 5-12 show the docked conformation of each 
Table 1. Dehydrosqualene synthase protein residues interact with selected molecules using GlideXP

\begin{tabular}{|c|c|c|c|}
\hline $\begin{array}{l}\text { Serial } \\
\text { No. }\end{array}$ & Ligands & Interacting residues of dehydrosqualene synthase & $\begin{array}{l}\text { Number of } \\
\text { Hydrophobic residue } \\
\text { interaction }\end{array}$ \\
\hline 1 & Binding_DB50292847 & $\begin{array}{l}\text { His18, Phe22, Phe26, Tyr41, Arg45, Asp48, Tyr129, Val133, Ala134, Gly135, } \\
\text { Val137, Gly138, Leu141, Leu145, Ala157, Leu160, Gly161, Leu164, Gln165, } \\
\text { Asn168, Ile241 }\end{array}$ & 11 \\
\hline 2 & MMs02489379 & $\begin{array}{l}\text { His18, Phe26, Tyr41, Cys44, Arg45, Asp48, Val111, Asp114, Tyr129, Val133, } \\
\text { Ala134, Val137, Leu141, Leu145, Ala157, Leu160, Gly161, Leu164, Gln165, } \\
\text { Asn168, Ile169, Arg171, Asp172, Glu175, Asp176, Arg181, Tyr183, lle241, } \\
\text { Arg265 }\end{array}$ & 16 \\
\hline 3 & BindingDB_50292854 & $\begin{array}{l}\text { His18, Phe22, Phe26, Tyr41, Arg45, Asp48, Val133, Ala134, Val137, Gly138, } \\
\text { Leu141, Thr142, Leu145, Ala157, Leu160, Gly161, Leu164, Gln165, Asn168, } \\
\text { Phe233, lle241, Ala244, Tyr248 }\end{array}$ & 15 \\
\hline 4 & MMs02489377 & $\begin{array}{l}\text { His18, Phe22, Phe26, Val37, Tyr41, Cys44, Arg45, Asp48, Asp49, Leu107, } \\
\text { Val111, Asp114, Tyr129, Val133, Ala134, Val137, Leu141, Leu160, Gly161, } \\
\text { Leu164, Gln165, Asn168, lle169, Arg171, Asp172, Asp176, Asn179, Arg181, } \\
\text { Tyr183, Arg265 }\end{array}$ & 15 \\
\hline 5 & Bhatia_52 & $\begin{array}{l}\text { His18, Phe22, Phe26, Arg45, Asp48, Val133, Ala134, Gly135, Val137, } \\
\text { Gly138, Leu141, Thr142, Leu145, Ala157, Leu160, Gly161, Leu164, Gln165, } \\
\text { Asn168 Phe233 }\end{array}$ & 15 \\
\hline 6 & Bhatia_51 & $\begin{array}{l}\text { His18, Phe22, Phe26, Tyr41, Ala134, Gly135, Val137, Gly138, Leu141, } \\
\text { Thr142, Leu145, Ala157, Leu160, Gly161, Leu164, Gln165, Asn168, Phe233, } \\
\text { Ile241, Ala244 }\end{array}$ & 13 \\
\hline 7 & 4oh-piper & $\begin{array}{l}\text { His18, Phe22, Phe26, Val37, Tyr41, Cys44, Arg45, Asp48, Tyr129, Val133, } \\
\text { Ala134, Val137, Gly138, Leu141, Leu145, Ala157, Leu160, Gly161, Leu164, } \\
\text { Gln165, Asn168, Arg171, Tyr183 }\end{array}$ & 15 \\
\hline 8 & PG02 & $\begin{array}{l}\text { Phe22, Phe26, Val37, Tyr41, Arg45, Asp48, Val133, Ala134, Val137, } \\
\text { Gly138, Leu141, Leu145, Ala157, Leu160, Gly161, Leu164, Gln165, Asn168 }\end{array}$ & 12 \\
\hline
\end{tabular}

selected ligands at the active site cavity of dehydrosqualene synthase protein (2ZCO) based on binding energy (GScore) which obtained by molecular docking using GlideXPMaestro. Each image shows the interaction of the ligand with a hydrophobic residue, and all amino acid residues of the protein synthase dehydrosqualene. Molecule PG02 does not have hydrogen bonding interactions with amino acid residues of protein target. Molecule of MMs02489379 and MMs02489377 have the most number of hydrogen bonding and

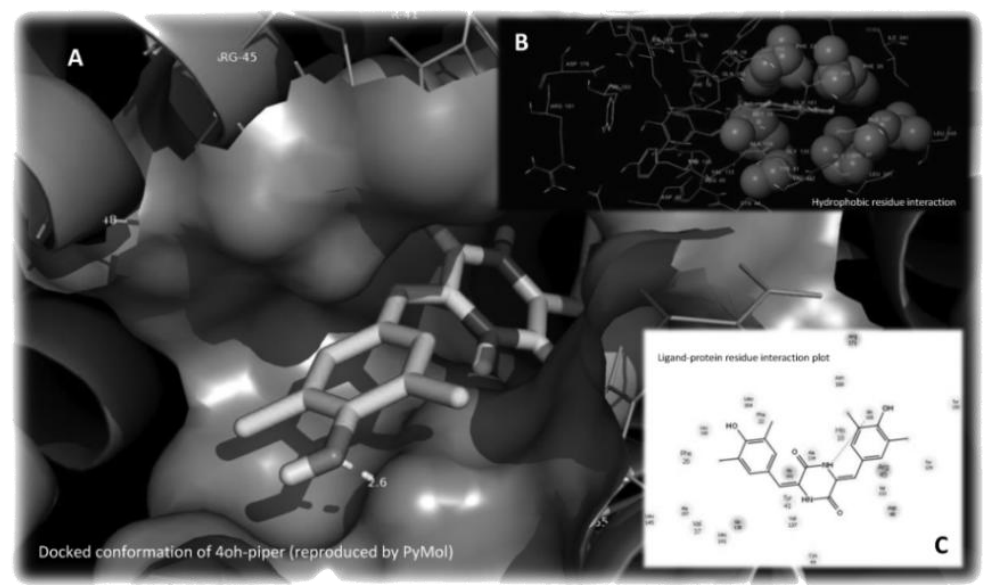

Figure 5. Docked conformation of 4oh-piper view, 5.b with hydrophobic residue interaction, and 5.c with interacting amino acids residue of dehydrosqualene synthase protein at the active site cavity.

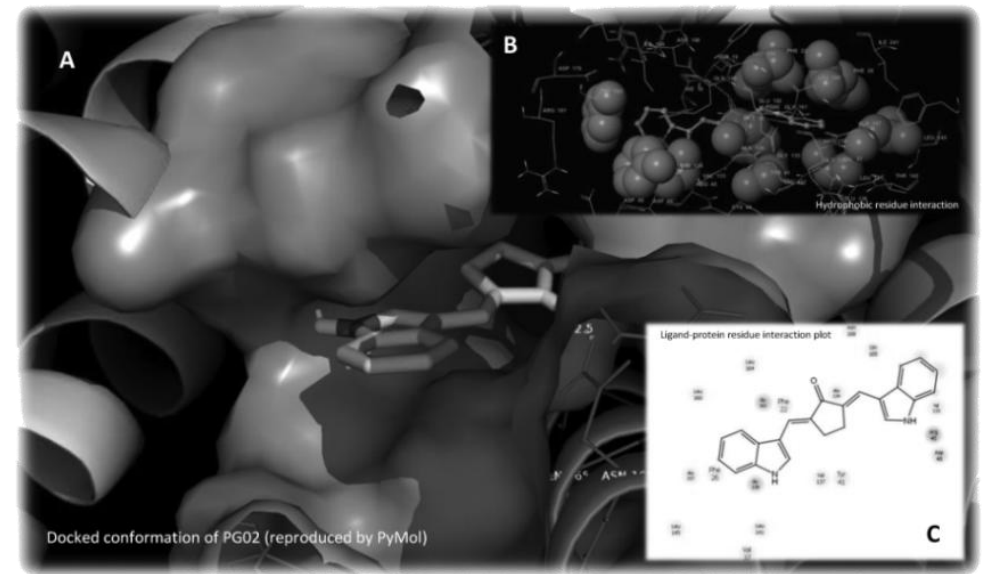

Figure 6. Docked conformation of PG02 view, 6.b with hydrophobic residue interaction, and 6.c with interacting amino acids residue of dehydrosqualene synthase protein at the active site cavity. 


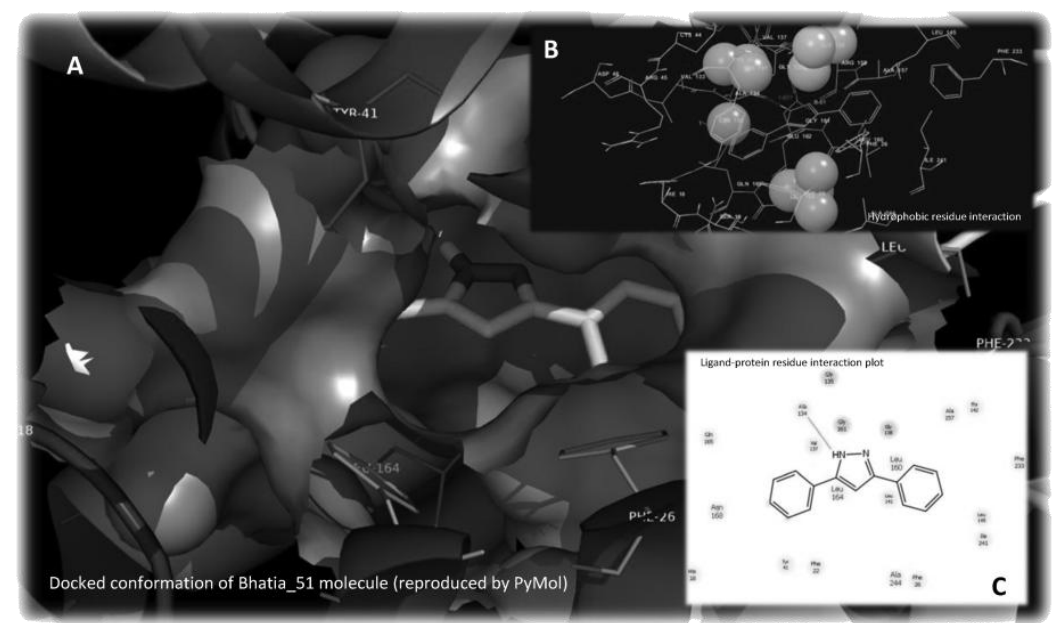

Figure 7. Docked conformation of Bhatia_51 molecule view, 7.b with hydrophobic residue interaction, and 7.c with interacting amino acids residue of dehydrosqualene synthase protein at the active site cavity.

amino acid residue interaction compared with method of fingerprint-based filtering of other ligands. They also have a value of shaped similarity scoring. The method GScore less than $-10 \mathrm{kcal} / \mathrm{mol}$. This is due all willselect ligands from database that have a the reference ligand obtained from the high compatibility with the binding site pocket MMsMIMICs database using the screening of protein target based on shaped similarity.

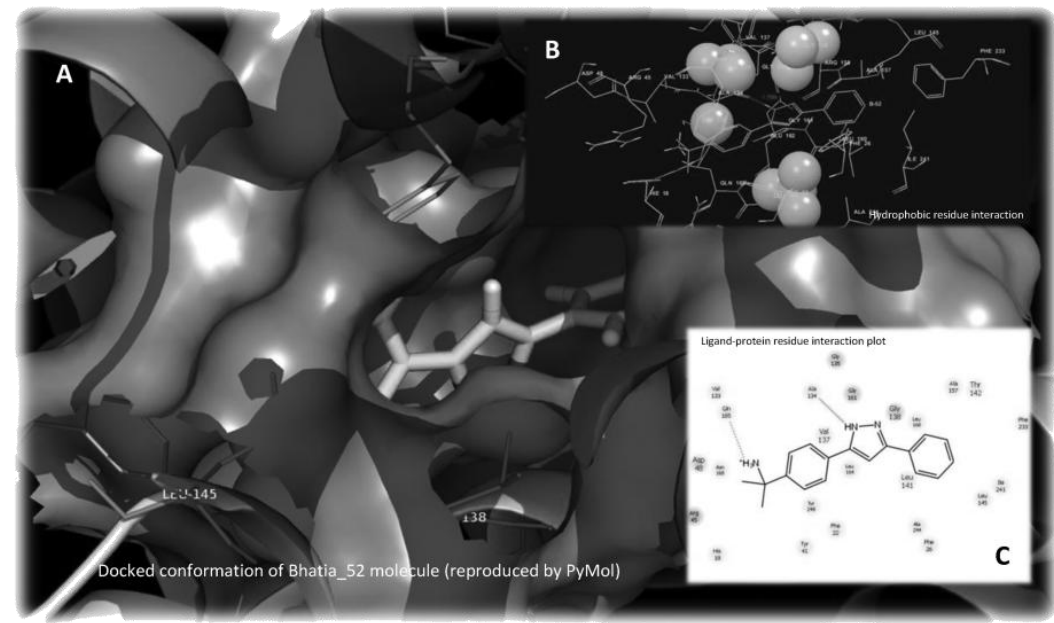

Figure 8. Docked conformation of Bhatia_52 molecule view, 8.b with hydrophobic residue interaction, and 8.c with interacting amino acids residue of dehydrosqualene synthase protein at the active site cavity.

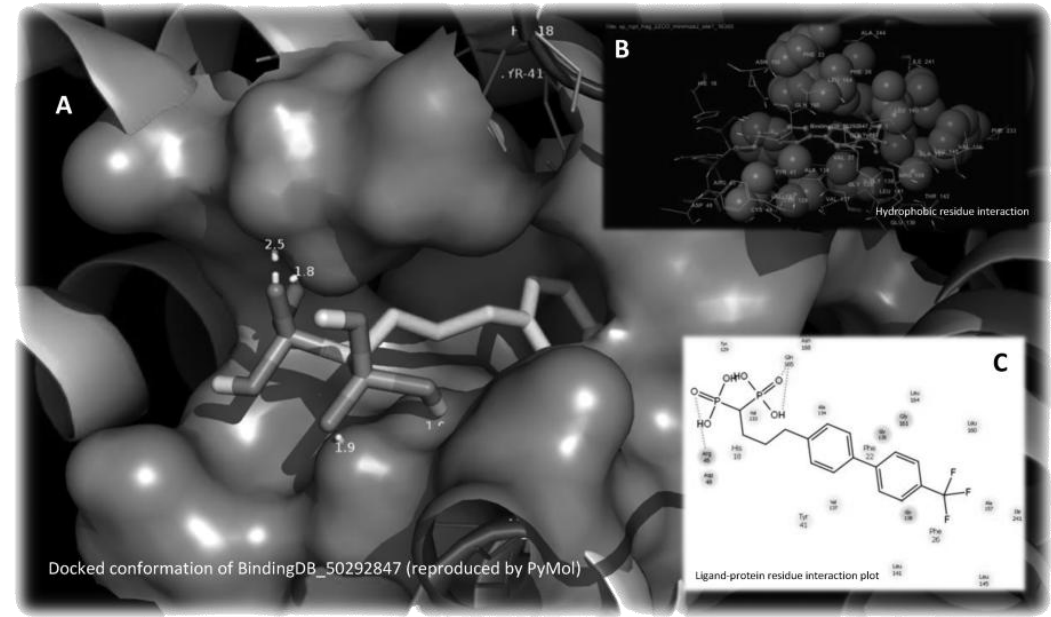

Figure 9. Docked conformation of BindingDB_50292847 molecule view, 9.b with hydrophobic residue interaction, and 9.c with interacting amino acids residue of dehydrosqualene synthase protein at the active site cavity. 


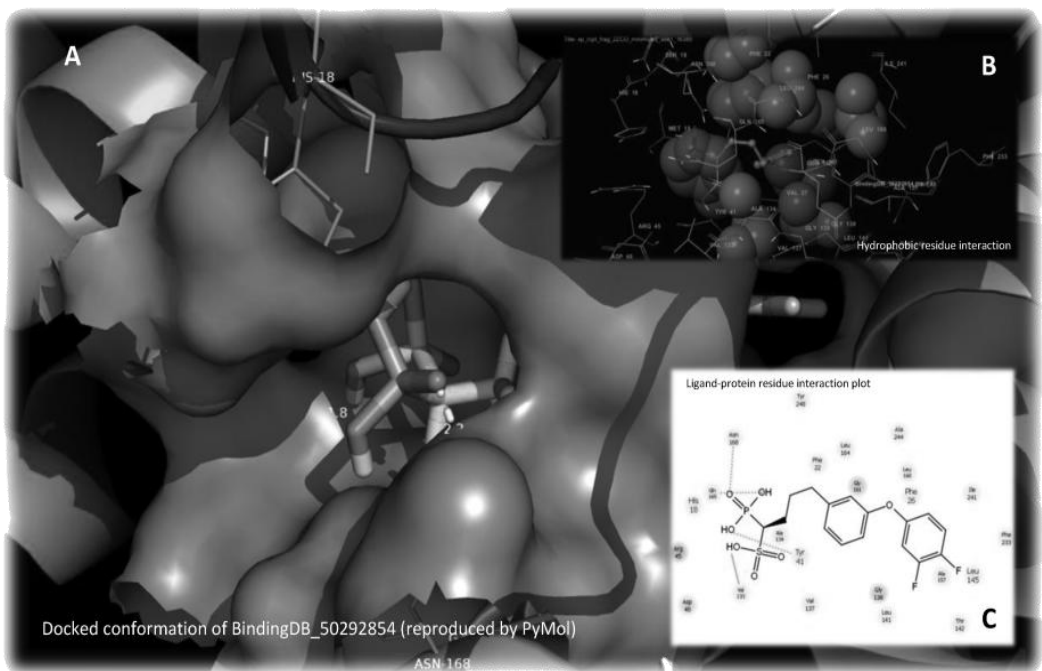

Figure 10. Docked conformation of BindingDB_50292854 molecule view, 10.b with hydrophobic residue interaction, and $10 . c$ with interacting amino acids residue of dehydrosqualene synthase protein at the active site cavity.

Three-dimensional of docked conformation of of van-piper has antibacterial activity against $S$. eight selected molecules with aureus and 4oh-piper has antibacterial activity dehydrosqualene synthase protein was shown against Bacillus subtilis (will published as in Figure 4 using GlideXP. It is indicate that Santoso et al, 2012; Santoso et al, 2011). sitemap_site_1 as main binding site pocket for Molecule of PG02 is predicted to have dehydrosqualene synthase. In group of antimicrobial activity also against S.aureus diketopiperazine analogues, molecule of $40 \mathrm{~h}-$ and $B$. subtilis. Table 1 present piper has the strongest predicted binding dehydrosqualene synthase protein residues affinity that showed by its lowest GScore then which interact with selected molecules using PG02 and van-piper (data not shown). Molecule

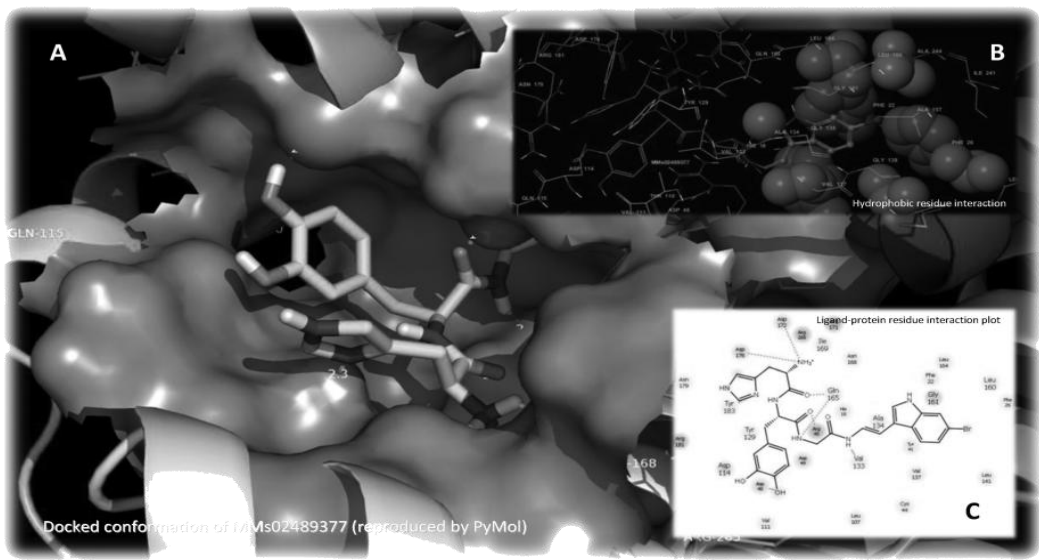

Figure 11. Docked conformation of MMs02489377 molecule view, 11.b with hydrophobic residue interaction, and 11.c with interacting amino acids residue of dehydrosqualene synthase protein at the active site cavity.

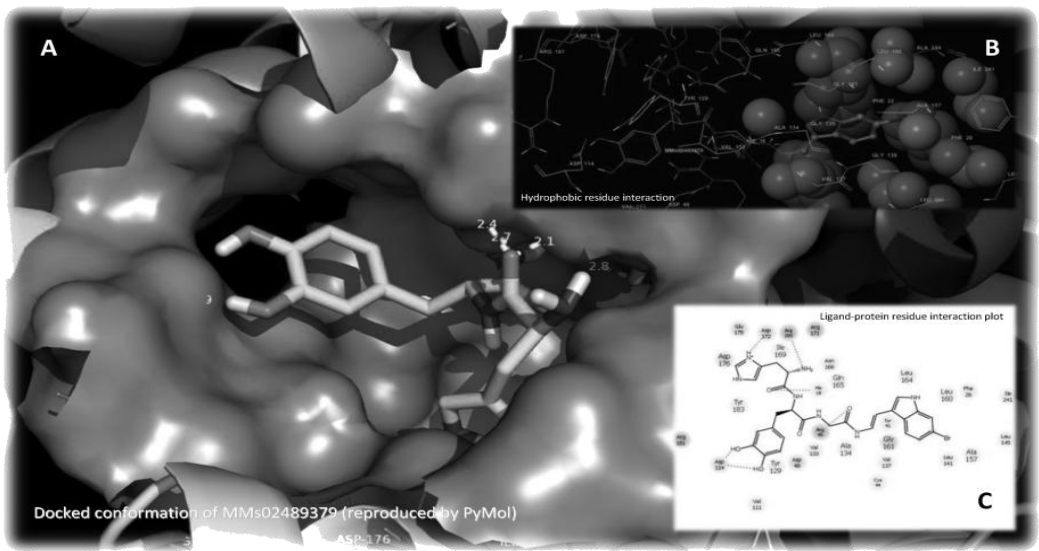

Figure 12. Docked conformation of MMs 02489379 molecule view, 12.b with hydrophobic residue interaction, and 12.c with interacting amino acids residue of dehydrosqualene synthase protein at the active site cavity. 


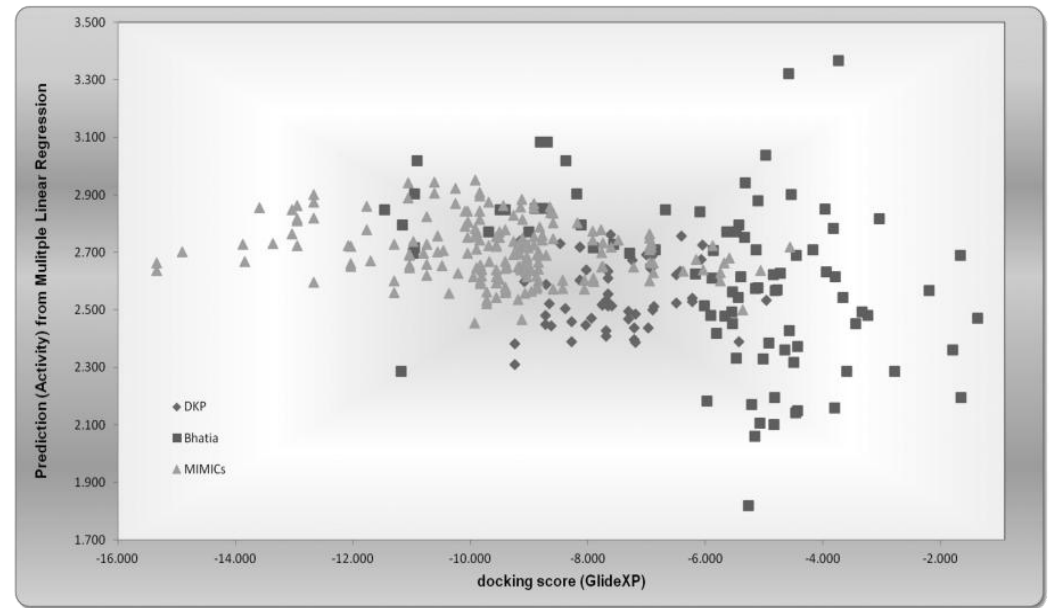

Figure 13. Distribution of docking scores (GScore) value with dehydrosqualene synthase protein versus Prediction activity value (based on Multiple Linear Regression) of selected group of ligand (diketopiprazine derivates, Bhatia research molecule, and MIMICs molecule).

GlideXP, and number of hydrophobic residues interaction.

These results are consistent with the primary QSAR descriptor of pyrazoline analogues interactions with dehydrosqualene synthase protein on Bhatia et al (2010) research but in contrast with previous research of molecular docking using AutoDock-Vina (Santoso, 2011 b). Figure 13 confirms that the diketopiperazine analogues still have a chance to be developed and further tested for antibacterial activity. The additions of functional groups containing halogens are expected to increase the antibacterial activity of diketopiperazine analogues.

\section{CONCLUSION}

The results suggest that the diketopiperazine framework is a prospective template for modification and optimization to accomplish better potency of antibacterial activity in laboratory testing.

\section{ACKNOWLEDGMENT}

Schrodinger, Inc., thanks for software Schrodinger Maestro, thanks to R. RAGHU and D. VINOD personally who have given author the knowledge and short tutorial for Schrodinger Maestro, and Faculty of Pharmacy Universitas Muhammadiyah Surakarta and Airlangga University for the opportunity to participate in Molecular Modeling Workshop in Surabaya.

\section{REFERENCES}

Bhatia, M. S., Ingale, K. B., Choudhari, P. B., Zarekar, B. E., Bhatia, N. M., and Sherikar, A. S., 2010, 3D QSAR: Exploring Influence of Parameters of Pyrazoline Analogues on Resistant Strains of Staphylococcus aureus, International Journal of Drug Design and Discovery, 1 (1), 41 48.

Cha, H.Y, Moon, D.C., Choi, C.H., Oh, J.Y., Jeong, Y.S., Lee, Y.C., Seol, S.Y., Cho, D.T., Chang, H., Kim, S., and Lee, J.C., 2005, Prevalence of the ST239 Clone of MethicillinResistant Staphylococcus aureus and Differences in Antimicrobial Susceptibilities of ST239 and ST5 Clones Identified in a Korean Hospital, Journal of Clinical Microbiology, 43 (8), p. 36103614.

Cikrikci, S., Mozioglu, E., and Yilmaz, H., 2008, Biological Activity of Curcuminoids Isolated from Curcuma longa, Rec. Nat. Prod., 2 (1), 19-24.

Cross, J. B., Thompson, D. C., Rai, B. K., Baber, J. C., Fan, K. Y., Hu, Y., dan Humblet, C., 2009, Comparison of Several Molecular Docking Programs: Pose Prediction and Virtual Screening Accuracy, J. Chem. Inf. Model., 49, 1455-1474.

Da'i, M., Meiyanto, E., Supardjan, A. M., Jenie, U. A., and Kawaichi, M., 2007, Potensi Antiproliferative Analog Kurkumin Pentagammavunon terhadap Sel Kanker Payudara T47D, Artocarpus, 7 (1), 14-20.

Dutta S., Burkhardt K., Swaminathan G.J., Kosada T., Henrick K., Nakamura H., Berman H.M., 2009, Data Deposition and Annotation at the Worldwide Protein Data Bank. Mol Biotechnol 42(1):1-13. doi:10.1007/s12033-008-9127-7. 
Floris, M., Masciocchi, J., Fanton, M., and Moro, S., 2011, Swimming into Peptidomimetic Chemical Space using pepMMsMIMIC, Nucl. Acids Res., May, 1-9.

Friesner, R. A., Murphy, R. B., Repasky, M. P., Leah L. Frye, L. L., Greenwood, J. R., Halgren, T. A., Sanschagrin, P. C., dan Mainz, D. T., 2006, Extra Precision Glide: Docking and Scoring Incorporating a Model of Hydrophobic Enclosure for Protein-Ligand Complexes, J. Med. Chem., 49, 6177-6196.

Frisch, M. J., et al, 2009, Gaussian 09, Revision A.02, Gaussian, Inc., Wallingford CT, ww.gaussian.com.

Krovat, E. M., Steind, T. dan Langer, T., 2005, Recent Advances in Docking and Scoring, Current Computer-Aided Drug Design, 1, 93-102.

Kubinyi, H., 1998, Structure-based Design of Enzyme Inhibitors and Receptor Ligands, Current Opinion in Drug Discovery and Development, 1 (1): 4-15.

Lestari, E.S., Severin, J.A., Filius, P.M.G., K. Kuntaman, K., Duerink, D.O., Hadi, U., Wahjono, H., and Verbrugh, H.A., 2008, Antimicrobial resistance among commensal isolates of Escherichia coli and Staphylococcus aureus in the Indonesian population inside and outside hospitals, Eur $J$ Clin Microbiol Infect Dis, 27, 45-51.

Lin, F., Liu, C., Liu, Y., Zhang, Y., Wang, K., Jeng, W., Ko, T., Cao, R., Wang, A.H.-J., and Oldfield, E., 2010, Mechanism of action and inhibition of dehydrosqualene synthase, PNAS, 107 (50), 21337-21342.

Liu, C., Liu, G.Y., Song, Y., Yin, F., Hensler, M.E., Wen-Yin Jeng, W., Nizet, V., Wang, A.H.J., and Oldfield, E., 2008, A Cholesterol Biosynthesis Inhibitor Blocks Staphylococcus aureus Virulence, Science, 319 (5868): 1391-1394. doi:10.1126/science.1153018.

Liu, G.Y., Essex, A., Buchanan, J.T., Datta, V., Hoffman, H.M., Bastian, J.F., Fierer, J., and Nizet, V., 2005, Staphylococcus aureus golden pigment impairs neutrophil killing and promotes virulence through its antioxidant activity, The Journal of Experimental Medicine, 202 (2), 209215.

Mardiastuti, H.W., Karuniawati A., Kiranasari, A., Ikaningsih, Kadarsih, R., 2007, Emerging Resistance Pathogen: Situasi Terkini di Asia, Eropa, Amerika Serikat, Timur Tengah dan Indonesia, Majalah Kedokteran Indonesia, 57 (3), 75-79.

Naz, S., Jabeen, S., Ilyas, S., Manzoor, F., Aslam, F., and Ali, A., 2010, Antibacterial Activity of Curcuma longa Varieties Against Different Strains of Bacteria, Pak. J. Bot., 42 (1), 455-462. Parameshwar, K. S., Kumar, B. A., Reddy, A. S. and Parthasarathy, T., 2009, Quantitative Structure Activity Relationship (QSAR) Studies of Quinolone Derivatives as Potential Antibacterial Agents, Rasayan J. Chem., 2 (1), 247-250.

Raghu, R., 2011, Workshop Material in Intensive Workshop on Recent Advances in Molecular Modeling and Drug Design Methods, UNAIR, Surabaya.

Rai, D., Singh, J. K., Roy, N., and Panda, D., 2008, Curcumin Inhibits FtsZ Assembly: an Attractive Mechanism for its Antibacterial Activity, Biochem. J., 410, 147-155.

Santosaningsih et al., 2008: Discharge MRSA screening of surgical patients in Indonesia. Proceeding, International Symposium on Staphylococci and Staphylococcal Infection, Australia.

Santoso, B., 2010, Docking of Curcumin Analogues Piperazinedione Derivates on Tubulin (1TUB) Chain $\beta$ Using Vina and AutoDock, Kongres IImiah IAI ke-18, Makasar, December, $10^{\text {th }}$.

Santoso, B., 2011 ${ }^{\mathrm{a}}$, Glide-XP Molecular Screening: Diketopiperazin Derivatives to Beta Chain of Tubulins (Skrining Molekular Glide-XP: Turunan Diketopiperazin terhadap Tubulin Rantai Beta), Proceeding, Simposium Nasional PERHIPBA XV, Hotel Sahid Jaya Solo, 9-10 November 2011.

Santoso, B., $2011^{\text {b }}$, 3D-Molecular Screening of Diketopiperazine Derivates on Staphylococcus aureus Dehydrosqualene Synthase using Vina, International Seminar on Medicinal Chemistry and Timmerman Award 2011, Faculty of Pharmacy, Airlangga University.

Santoso, B., and Supardjan, A.M., 2010, Radical Scavenging Activity of 3,6-bis[(4-hydroxy-3methoxyphenyl)methyliden]piperazine-2,5-dione and 3,6-bis[(4-hydroxy-3,5-dimethylphenyl) 
methyliden]piperazine-2,5-dione on 2,2-diphenyl-1-picrylhydrazyl (DPPH), Proceeding, Seminar Nasional Eight Star Performance Pharmacist, Faculty of Pharmacy, Gadjah Mada University, Yogyakarta, December, $27^{\text {th }}$.

Santoso, B., Shani, Y.M., Haryoto, and Ulfa, A.M., 2012, Antibacterial Activity of 3,6-bis[(4hydroxy-3-methoxyphenyl)methylidene]piperazine-2,5-dione and 3,6-bis[(4-hydroxy-3,5dimethylphenyl)methylidene]piperazine-2,5-dione to Staphylococcus aureus, Escherichia coli, and Bacillus subtilis, will published on International Seminar on Natural Product Medicines, ITB, Bandung, 22-23 November 2012.

Shani, Y. M., Santoso, B., and Haryoto, 2011, Antibacterial Activity of 3,6-bis[(4-hydroxy-3methoxyphenyl)methyliden]piperazine-2,5-dione and 3,6-bis[(4-hydroxy-3,5-dimethylphenyl) methyliden]piperazine-2,5-dione on Bacillus subtilis and Propionibacterium acne, Thesis, Faculty of Pharmacy, Universitas Muhammadiyah Surakarta.

Song, Y., Lin, F., Yin, F., Hensler, M., Poveda,C.A.R., Mukkamala, D., Cao, R., Wang, H., Morita, C.T., Pacanowska, D.G., Nizet, V., and Oldfield, E., 2009, Phosphonosulfonates Are Potent, Selective Inhibitors of Dehydrosqualene Synthase and Staphyloxanthin Biosynthesis in Staphylococcus aureus, J. Med. Chem., 52, 976-988.

Sunilson, J. A. J, Suraj, R., Rejitha, G., Anandarajagopal, K., Kumari, A. V. A. G, and Promwichit, P., 2009, In vitro Antimicrobial Evaluation of Zingiber officinale, Curcuma longa and Alpinia galanga Extracts as Natural Food Preservatives, American Journal of Food Technology, 4 (5), 192-200.

The PyMOL Molecular Graphics System, Version 1.4.1, Schrödinger, LLC.

Triyana, S.Y., 2009, Antibiotic Resistence of Pathogenic Bacteria, Majalah Kesehatan PharmaMedika, 1 (2), 92-94.

Trylska, J., Tozzini, V., Chang, C.A., and McCammon, J.A., 2007, HIV-1 Protease Substrate Binding and Product Release Pathways Explored with Coarse-Grained Molecular Dynamics, Biophysical Journal, 92, 4179-4187.

Villemin, D., and Alloum, A. B., 1990, Potassium Fluoride On Alumina: Condensation of 1,4Diacetylpiperazin-2,5-Dione with Aldehydes. Dry Condensation Under Microwave Irradiation. Synthesis of Albonursin and Analogues, Synthetic Communications, 20 (21), 3325-3331.

Waszkowycz, B., Clark, D. E., and Gancia, E., 2011, Outstanding Challenges In ProteinLigand Docking and Structure-Based Virtual Screening, WIREs Computational Molecular Science, 1, March/April 2011.

Xiaoqi, S., dan Zhehao, Z., 2006, Molecular Docking and Virtual Screening Assessment: Application to PI3Ky, Thesis / Master of Science/ Bioinformatics, Chalmers University of Technology, Göteborg, Sweden. 